\title{
The Influence of Land Rental Market on Non-farm Employment: Evidences from Zhejiang, Hubei, Shaanxi Province
}

\author{
Tian Chuanhao ${ }^{1}$, Li Mingkun ${ }^{2, a}$ \\ ${ }^{1}$ Department of Public Administration, Zhejiang University, 310058 Hangzhou Zhejiang, China. \\ ${ }^{2}$ Department of Public Administration, Zhejiang University, 310058 Hangzhou Zhejiang, China.
}

\begin{abstract}
Using the first-hand survey data from Zhejiang, Hubei and Shaanxi in 2011, this study tries to measure the degree of the development of the rural land rental market comprehensively, from both the "quality" and the "quantity" aspects. At the same time, it will analyze how the rural land rental market of the village affects the non-farm employment decisions of the rural labors. The empirical results show that both the "quality" and "quantity" of the rural land market have a significant impact on the non-farm employment decisions of the rural labors. The mature rural land rental market with stable contracts can promote the non-farm employment of the rural labors. Furthermore, the short-term land rental contract has no significant effect on the rural labors' non-farm employment; the long-term land rental contract has a significant effect on the rural labors' non-farm employment. From the public policy perspective, only the public policies aiming to promote the farmers to sign a long-term rental contract can increase the rural labors' non-farm employment effectively.
\end{abstract}

Keywords. land rental market; non-farm employment; the stability of land tenure

\section{Introduction}

Law of Rural Land Contract, enacted in 2002, stipulated that contractor enjoy the right of contracted land use, income and management by law. Rural land market obtained its legal protection then. And with the increasingly active moving of rural surplus labor to non-agricultural sectors, it got a further development. But it remains in a beginning yet. Land rental market is not very mature in China at present. It is regional and varies greatly from the other (Jianping Ye et al, 2006a; Zhonghao Qian, Yan Mou, 2012).

Mature land market can promote non-agricultural employment of rural labor because of its effective promotion of agricultural land transfer and family labor move (Jianhua Cao et al, 2007). Since labor allocated between agricultural and non-agricultural sector, many scholars (Yang Yao, 2000; Kung, 2002; Deininger et al., 2005, 2008; Jikun Huang et al., 2012) believe that, due to the higher income of non-agricultural sector, more farmers choose to engage in non-agricultural sectors and less labor to farmland management. So families engaged in non-agricultural industries are more likely to rent land, especially for those work outside the village. They made a lot of research from the

${ }^{a}$ Corresponding author: limingkun89@126.com 
perspective of farmer's microeconomic decisions and gained rich achievements. Unfortunately, endogenous problem between farmland circulation and labor flow have not been well considered, and the effects can wreak havoc with those results. But, if we based on the perspective of village, this problem can be solved. Because, the development of rural land market is determined collectively by all farmers' rural land transfer decisions inside the village. It will not impact on rural labor's off-farm employment decision in theory.

In addition, the development of rural land market includes two sides. On the one hand, development on quantity, such as the number of rural land transferred. Development on quality, on the other hand, emphasizes more on the stability of land-lease contracts (Tian Chuanhao, Li Fang, 2013). Rural land market of high quality, can provide farmers with more stable and guaranteed contract market and offer labor flow a long stable expectation.

In this paper, we focus on the influence of land rental market on non-farm employment from the perspective of village. As mentioned above, this is an effective way to solve endogenous problem between farmland circulation and labor flow. Moreover, the article makes an in-depth analysis based on comprehensive measure of the development of rural land market from the quantity and quality dimensions.

The remainder of this article is structured as follows. In the second section, we first review the theoretical and empirical literature on the relationship between non-farm employment and land rental market. On this basis, the third section addresses the design of the empirical research. In the fourth section, we move on with our own analysis on the influence of land rental market on non-farm employment. We further address the influence with difference of rural land market. And the final section provides a conclusion.

\section{Literature review}

\subsection{Non-farm employment and land rental market}

From the perspective of farmers' non-farm employment decisions and land transfer decisions, Yaohui Zhao (1999), Feng (2008), Feng et al. (2008) and Jikun Huang et al. (2012) have investigated the interactive relationship between non-farm employment and land rental market. Shuyi Feng (2008) concludes that there is a significant negative correlation between non-farm employment and rural land transfer based on the data of three villages in the northeast Jiangxi province. They affect each other and restrict each other. In this sense, it is impossible to achieve non-farm employment and rural land transfer at the same. More non-farm employment opportunities and more effectively operational efficiency of rural land market would be pulling into a dead end. And some other scholars (Jie Zhang, Peimin Zhan, 2005; Yuna Sun et al., 2012) claim that the relationship between non-farm employment and rural land transfer are more unstable primarily due to the imperfect of social security system and farmland system.

\subsection{Influence of non-farm employment on land rental market}

Many scholars (Yang Yao, 2000; Kung, 2002; Deininger et al., 2005, 2008; Jikun Huang et al., 2012) have made empirical research from different perspectives, agreed that labor mobility significantly promote the transfer of rural land. Kung (2002) found that the start of land rental market is consistent in time with the accelerating development of non-farmer labor market from the analysis of phased characteristics of development. He further reasoned, non-farmer labor market is the main catalyst in the development of land rental market. Families actively engaged in non-farm employment would rent less land. From the perspective of heterogeneity of farmers' productivity, Yang Yao (1999, 2000) found that free labor market can promote the development of land rental market. Differences in productivity determine the differences in farmers' land circulation decisions. With the view of economic development, Deininger et al. (2008) pointed out that land leasing would be more active where non-farm activities more frequently. 


\subsection{Influence of land rental market on non-farm employment}

At present, few scholars pay attention to the influence of land rental market on non-farm employment and related articles are much fewer. Based on the data of 30 provinces in China, Heyuan You et al. (2010) found that many factors impact on non-farm employment through rural land circulation, including industrialization level in countryside, farmer's farmland endowment, investment level of agricultural mechanization and the social security function of farmland. Kung et al. (2001) pointed out that for rural male labor, active land rental market are negatively related with their non-farm employment. Kung's explanation is, if they can expand the scale of farm work to reap benefits, they do not need to give up farming. However, the premise of Kung's explanation is that expand the scale of farm is negatively related to non-farm employment. Cognate recurrences weakened his arguments.

Overall, there are still many limitations in the existing related studies: (1)very few empirical studies have been executed to analyze the influence of rural land market on non-farm employment; (2) the endogenous problem between farmland circulation and labor flow has long troubled scholars and ideal instrument variables are hard to find; (3) the development of rural land market includes two sides, but existing studies tend to consider the amount of land market transaction, and ignore the quality of the land market. In this paper, we focus on the influence of land rental market on non-farm employment from the perspective of village and well solved the endogenous problem between farmland circulation and labor flow. Meanwhile, measuring the development of rural land market from the quantity and quality dimensions is more scientific and comprehensive.

\section{Research design}

\subsection{Data source}

In July 2011, we conducted home investigations and field research in Zhejiang, Hubei and Shaanxi Province. The survey covered a total of 54 villages of 19 towns in 9 cities, collected data from 1134 families and 4565 family members. We used stratified random sampling to select respondents, and respectively designed questionnaire for village cadres and of villagers. We used face-to-face interview in villager data collection. Therefore, those worked outside the village were not included. And these farmers are more likely to have land rent out. For this reason, we only take contract period of farmland rent in as the analysis object.

\subsection{Quality and quantity development of rural land market}

Considered that farmer signed lease contracts with farmers' collective organization and other farmers, we take weighted average time of land transfer contract period as the measure index of quality development of land market. In order to eliminate the influence of farming scale, we take the amount of land circulation as a percentage of total cultivated area as the quantity development of land market.

\subsection{Variables selection}

To avoid simultaneous engagement situation, we select rural labor's migrating employment as explained variable and development of rural land market on village level as explaining variable. Other factors can also have impacts on the non-farm employment, see table 1. 
Table 1. Measure and choice basis of variables

\begin{tabular}{|c|c|c|c|}
\hline Type & $\begin{array}{l}\text { Conceptual } \\
\text { variable }\end{array}$ & Measure of variables & Choice basis of variables \\
\hline $\begin{array}{l}\text { Dependent } \\
\text { variable }\end{array}$ & $\begin{array}{l}\text { Non-farm } \\
\text { employment } \\
\text { decisions }\end{array}$ & $\begin{array}{c}\text { Engaged in non-farm work or not in } 2010 \\
\quad(1=\text { yes, } 0=\text { not }) \\
\begin{array}{c}\text { Time of non-farm work outside the } \\
\text { village in } 2010 \text { (months) }\end{array}\end{array}$ & \\
\hline $\begin{array}{c}\text { Independent } \\
\text { variable }\end{array}$ & $\begin{array}{c}\text { Development of } \\
\text { rural land market }\end{array}$ & $\begin{array}{l}\text { Weighted average time of land transfer } \\
\text { contract period } \\
\text { Amount of land circulation as a } \\
\text { percentage of total cultivated area }\end{array}$ & Feng et al.,2008 \\
\hline \multirow{4}{*}{$\begin{array}{l}\text { Control } \\
\text { variable }\end{array}$} & $\begin{array}{c}\text { Personal } \\
\text { characteristics }\end{array}$ & $\begin{array}{c}\text { Gender }(1=\text { male, } 0=\text { female }) \\
\text { Age }(\text { year }) \\
\text { Square of age } \\
\text { Level of education }(0=\text { none, } 1=\text { primary } \\
\text { school }, 2=\text { junior high school, } 3=\text { senior } \\
\text { high school, } 4=\text { technical secondary } \\
\text { school, } 5=\text { junior college, } 6=\text { university } \\
7=\text { others })\end{array}$ & $\begin{array}{c}\text { Alan de Brauw,2002 } \\
\text { Zhang Qian Forrest et } \\
\text { al.,2004;Kung,2002 } \\
\text { Feng et al.,2008 } \\
\text { Ting Li et al., 2009; Xianlei Ma, } 2010\end{array}$ \\
\hline & $\begin{array}{c}\text { Family } \\
\text { characteristics }\end{array}$ & $\begin{array}{l}\text { Family size (person) } \\
\text { Distributed number of cultivated land }\end{array}$ & $\begin{array}{c}\text { Kung,2002;Feng et al.,2008 } \\
\text { Yaohui Zhao,1999 }\end{array}$ \\
\hline & $\begin{array}{c}\text { Village } \\
\text { characteristics }\end{array}$ & $\begin{array}{c}\text { Per capita net income } \\
\text { Land redistribution or not } \\
\text { Land requisition or not since second } \\
\text { round contract }\end{array}$ & $\begin{array}{c}\text { Chuanhao Tian, Li Fang, } 2013 \\
\text { Xiaoyu Liu, Linxiu Zhang, 2008; Yang } \\
\text { Yao, 1999, } 2000\end{array}$ \\
\hline & Dummy variable & Virtual-province variable & Kung et al.,2001 \\
\hline
\end{tabular}

\subsection{Specification of model}

Since non-farm employment decisions is binary dependent variable, empirical research uses Logit and Probit model to test. And because of the sample of families all worked out is missing, the article select intercept regression model, namely Tobit model. Besides, the article using grouping regression method to analyze the influence of rural land market with different quality on non-farm employment.

\section{Empirical test}

\subsection{Influence of rural land market}

Logit, Probit and Tobit model results show that the quantity and quality development of rural land market have a significant positive influence on non-farm employment (see table 2). The longer land lease contracted and more land transferred, the more non-farm employment and longer non-farm working time.

From the results of Logit model, land lease contract extend 1 year, non-farm employment opportunities will increase by $1.9 \%$. Also, land circulation area ratio increase by $1 \%$ of the total area of village land, non-farm employment opportunities will increase by $1.49 \%$. Probit model shows similar trend. In Torbit model, land lease contract extend 1 year, the number of land circulation ratio increase by $1 \%$ of the total area of village land, non-farm working time will increase by 0.114 and 2.292 months respectively under the condition of controlling other variables. And the results of control 
variables are consistent with the basic academic understands.

Table 2. Empirical results of influence of land rental market on non-farm employment

\begin{tabular}{|c|c|c|c|c|c|}
\hline & & Explained variable & Logit model & Probit model & Tobit model \\
\hline Explaining & variable & & $\begin{array}{c}\text { Engaged in non-farm } \\
\text { work or not }\end{array}$ & $\begin{array}{c}\text { Engaged in non-farm } \\
\text { work or not }\end{array}$ & $\begin{array}{c}\text { Time of non-farm } \\
\text { work outside the } \\
\text { village }\end{array}$ \\
\hline & Constant & term & $-4.364^{* * *}$ & $-2.307^{* * *}$ & $-31.526^{* * *}$ \\
\hline $\begin{array}{c}\text { Explaining } \\
\text { variable }\end{array}$ & $\begin{array}{r}\text { Weighted as } \\
\text { transfer } \\
\text { Amount of } 1 \\
\text { percentage of }\end{array}$ & $\begin{array}{l}\text { erage time of land } \\
\text { contract period } \\
\text { and circulation as a } \\
\text { total cultivated area }\end{array}$ & $\begin{array}{c}0.019^{* * *} \\
0.378^{*}\end{array}$ & $\begin{array}{l}0.012^{* * *} \\
0.224^{*}\end{array}$ & $\begin{array}{l}0.114^{* * *} \\
2.292^{*}\end{array}$ \\
\hline & & $\begin{array}{l}\text { Gender } \\
\text { Age }\end{array}$ & $\begin{array}{l}-0.697^{* * *} \\
0.286^{* * *}\end{array}$ & $\begin{array}{l}-0.428^{* * * *} \\
0.149^{* * *}\end{array}$ & $\begin{array}{l}-4.359^{* * *} \\
1.997^{* * *}\end{array}$ \\
\hline & $\begin{array}{c}\text { Personal } \\
\text { characteristics }\end{array}$ & Square of age & $-0.004^{* * *}$ & $-0.002^{* * *}$ & $-0.030^{* * *}$ \\
\hline & & Level of education & $0.137^{* * *}$ & $0.086^{* * *}$ & $0.988^{* * *}$ \\
\hline Control & $\begin{array}{c}\text { Family } \\
\text { characteristics }\end{array}$ & $\begin{array}{c}\text { Family size } \\
\text { Distributed number } \\
\text { of cultivated land }\end{array}$ & $\begin{array}{l}0.178^{* * *} \\
-0.012\end{array}$ & $\begin{array}{c}0.101^{* * *} \\
-0.006\end{array}$ & $\begin{array}{c}1.041^{* * *} \\
-0.072\end{array}$ \\
\hline & Village & $\begin{array}{l}\text { Per capita net } \\
\text { income }\end{array}$ & $-0.097^{* * *}$ & $-0.057^{* * *}$ & $-0.577^{* * *}$ \\
\hline & characteristics & $\begin{array}{l}\text { Land redistribution } \\
\text { Land requisition }\end{array}$ & $\begin{array}{l}0.232^{* *} \\
-0.173^{*}\end{array}$ & $\begin{array}{l}0.131^{* *} \\
-0.099^{*}\end{array}$ & $\begin{array}{l}1.407^{* *} \\
-0.927^{*}\end{array}$ \\
\hline & & Zhejiang Province & 0.147 & 0.089 & $1.584^{*}$ \\
\hline & $v_{a l}$ & Hubei Province & $0.204^{* *}$ & $0.110^{*}$ & $1.488^{* *}$ \\
\hline
\end{tabular}

Data sources: field research conducted by China's rural household land management investigation team. $*, * *, * * *$ respectively stands for the $0.1,0.5$ and 0.01 significance level.

\subsection{Influence of different development of rural land market}

Empirical analysis shows that the quantity and quality development of rural land market play a significant role in improving non-farm employment. In this part, we used grouping regression method to analyze the influence of rural land market with different quality on non-farm employment. We divided the weighted average time of land transfer contract period into three groups, $[0,2),[2,8]$ and $(8,30]$, respectively covered 2380 samples of 27 villages, 1075 of 13 and 1110 of 14 . Since our focus is the influence of rural land market with different quality on non-farm employment, only explain variables are showed in grouping regression results (see table 3). Logit, Probit and Tobit model results show that the influence of weighted average time of land transfer contract period is significant in group $(8,30]$, but not in group $[0,2)$ and $[2,8]$. And the influence of amount of land circulation as a percentage of total cultivated area is not significant in all groups. 
Specific to see, Logit model results show that land lease contract extended 1 year on average, the possibility of non-farm employment will increase by $5.1 \%$ of, gteater than $1.019 \%$ of all samples. Similarly, Tobit model results indicate that land lease contract extended 1 year on average, non-farm working time will increase by 0.356 months of group $(8,30]$, greater than 0.114 of all samples. Judging from this, the influence of land lease contract over 8 years is more significant in promoting non-farm employment.

Table 3. Influence of rural land market with different quality on non-farm employment

\begin{tabular}{|c|c|c|c|c|c|c|c|c|c|c|}
\hline \multirow{2}{*}{\multicolumn{2}{|c|}{ Explaining variable }} & \multicolumn{3}{|c|}{ Logit model } & \multicolumn{3}{|c|}{ Probit model } & \multicolumn{3}{|c|}{ Tobit model } \\
\hline & & {$[0,2)$} & {$[2,8]$} & $(8,30]$ & {$[0,2)$} & {$[2,8]$} & $(8,30]$ & {$[0,2)$} & {$[2,8]$} & $(8,30]$ \\
\hline \multicolumn{2}{|c|}{ Constant term } & $-4.881^{* *}$ & $-5.050^{* *}$ & $-3.667^{* *}$ & $-2.651^{* *}$ & $-2.614^{* *}$ & $-1.898^{* *}$ & $-34.524^{*}$ & -28.644 & $-32.924^{*}$ \\
\hline \multirow{2}{*}{$\begin{array}{c}\text { Explaining } \\
\text { variable }\end{array}$} & $\begin{array}{c}\text { Weighted } \\
\text { average time of } \\
\text { land transfer } \\
\text { contract period }\end{array}$ & 0.153 & -0.013 & $0.050^{* * *}$ & 0.092 & -0.018 & $0.030^{* * *}$ & 0.576 & 0.410 & $0.356^{* * *}$ \\
\hline & $\begin{array}{l}\text { Amount of land } \\
\text { circulation as a } \\
\text { percentage of } \\
\text { total cultivated } \\
\text { area }\end{array}$ & 0.423 & 0.204 & -0.435 & 0.224 & 0.181 & -0.269 & 1.677 & 2.956 & -5.875 \\
\hline
\end{tabular}

Data sources: field research conducted by China's rural household land management investigation team. $*, * *, * * *$ respectively stands for the $0.1,0.5$ and 0.01 significance level.

\section{Conclusions and prospects}

In this paper, we focus on the influence of land rental market on non-farm employment from the perspective of village, well solved the endogenous problem between farmland circulation and labor flow and comprehensive measured the development of rural land market from the quantity and quality dimensions. Logit, Probit and Tobit model results shows that the quantity and quality development of rural land market play a significant role in improving non-farm employment. The longer land lease contracted and more land transferred, the more non-farm employment and longer non-farm working time. Grouping regression results show that land lease contract over 8 years is significant in promoting non-farm employment, but those short to medium term is not. The policy implications of the findings is promoting long-term land lease contract policy is the effective way to dilute surplus rural labor force and stimulate rural development in all rounds.

Of course, there still exist several drawbacks such as the limited survey data. Lacking of the data of duration of signed land lease contract of village to measure the quality of land market, we replace it by weighted average time of farmers surveyed. And it would almost surely that duration of signed land lease contract of village can better reflect the quality of rural land market and solve the endogenous problem between farmland circulation and labor flow. This will also become the direction of further research.

\section{References}

1. Alan de Brauw, Huang Jikun, Rozelle Scott, Zhang Linxiu, Zhang Yigang. The Evolution of China's Rural Labor Markets During the Reforms[J].Journal of Comparative Economics, 2002, 30:329-353 
2. Deininger Klaus, Jin Songqing. The potential of land rental markets in the process of economic development: Evidence from China[J].Journal of Development Economics,2005,78:241-270

3. Deininger Klaus, Jin Songqing,Hari K. Nagarajan. Efficiency and equity impacts of rural land rental restrictions: Evidence from India[J].European Economic Review,2008,52:892-918

4. Shuyi Feng. Land rental, off-farm employment and technical efficiency of farm households in Jiangxi Province, China[J]. Wageningen Journal of Life Sciences, 2008,55(4):363-378

5. Shuyi Feng, Heerink.N. Are farm households' land renting and migration decisions inter-related in rural China?[J].Wageningen Journal of Life Sciences,2008,55(4):345-362

6. Jikun Huang, Liangliang Gao, Rozelle Scott. The effect of off-farm employment on the decisions of households to rent out and rent in cultivated land in China[J].China Agricultural Economic Review,2012,4(1):5-17

7. Kung James Kai-sing. Off-Farm Labor Markets and the Emergence of Land Rental Markets in Rural China[J].Journal of Comparative Economics 2002(30):395-414

8. Kung James Kai-sing. So What if There Is Income Inequality? The Distributive Consequence of Nonfarm Employment in Rural China[J].Economic Development and Cultural Change, 2001, 50(1):19-46

9. Yang Yao. The Development of the Land Lease Market in Rural China[J].Land Economics,2000,76(2):252-266

10. Yang Yao. Egalitarian Land Distribution and Labor Migration in Rural China[R].2001,10

11. Linxiu Zhang, Jikun Huang, Rozelle Scott. Employment, emerging labor markets, and the role of education in rural china[J].China Economic Review,2002,13:313-328

12. Yaohui Zhao. Leaving the Countryside: Rural-to-urban Migration Decisions in China[J].the American Economic Review. 1999, 89:281-286

13. Jianhua Cao, Hongying Wang, Xiaomei Huang. Study on Supply and Demand Willingness of Rural Land Transaction Evaluation of Transaction Effeicency[J]. China Land Science. 2007, 21(5): 54-60

14. Xianlei Ma, Futian Qu. The Impact of Land Tenure Security on the Development of Land Rental Market under the New Farmland System[J]. China Land Science. 2010(9): 4-10.

15. Zhonghao Qian, Yan Mou. Regional Difference of Land Marketization in China[J]. Jiangsu Social Sciences. 2012(4):45-53.

16. Chuanhao Tian, Li Fang. Land Adjustment and Land Rental Market: Based on the Dual Perspectives of both Quantity and Quality [J].Economic Research Journal. 2013(2):110-121.

17. Yang Yao. Non-farm Employment Structure and the Development of Land Rental Mmarket[J]. China Rural Survey. 1999(2):16-37.

18. Heyuan You, Cifang Wu. Farmland Circulation, Endowment Dependence and Rural Labor Migration[J]. Management World.2010(3):65-75. 